\title{
Madoff's Victims and Their Day in Court
}

\author{
Lionel S. Lewis
}

Published online: 24 July 2010

(C) Springer Science+Business Media, LLC 2010

In light of the epidemic of financial malfeasance reported in the media following the recent economic downward spiral, almost everyone now knows what "too big to fail" and "housing bubble" mean, and that Ponzi schemes are investment operations that pay returns and redemptions to early investors not from profits, but from the money of subsequent investors. Although this form of white-collar crime has long existed, because of the immense scope of his scam, it is named after Charles Ponzi, who, in the early 1920s in the U.S., conceived and orchestrated a plan to buy vouchers for postage cheaply in one country and then immediately sell them for a profit in a country where postage was more expensive. We have learned a great deal about Ponzi, his biography and how he fooled so many. We have learned a lot less about the effects of his criminal activity, whom he plundered and about their lives after his crime was uncovered. We know too little about victims of white-collar crime, beginning with its social and psychological costs to individuals and families.

Recently, in December 2008, Bernard L. Madoff, who founded and managed an investment advisory company which provided services to individuals and organizations, was arrested for defrauding thousands of individuals and organizations of billions of dollars for over two decades. In March 2009, Madoff pleaded guilty of soliciting funds to buy securities and failing to invest the money, using it instead, as did Charles Ponzi, to pay returns to early investors and for his own benefit. According to the office of the United States Attorney, at the end of November of 2008, Madoff's investment advisory company had approx-

L. S. Lewis $(\bowtie)$

17 Morningside Lane,

Williamsville, NY 14221, USA

e-mail: socls1@buffalo.edu imately 4,900 client accounts, and reported that they held a balance of $\$ 64.8$ billion. In fact, after his arrest, these investments were found by the government to be worth "only a small fraction" of that amount. Indeed, federal prosecutors were able to show, for example, that the total net losses for approximately 1,341 accounts in which investments were first made between December 1995 and December 2008, were $\$ 13.2$ billion. Clearly the global reach of Madoff's swindle was enormous: individuals and institutions from over 40 countries, 339 funds of funds, and 59 management companies were invested with him.

Madoff's swindle has been well covered in the media, and we have learned much about his early childhood and young adulthood, his career, his lifestyle, his family, his friends, and how he duped so many. There are many accounts of how he operated, or how it is believed he operated. Like others who have had long running Ponzi schemes, Madoff relied on word of mouth and social networks to find investors. Some found out about him from their accountants, from their brokers, from their dentists, from bridge partners, and from relatives. He, and those who solicited funds for him, often did not rely only on business settings, but on social settings, to find people to bilk. They found investors through friends, in country clubs and yacht clubs, and at ski resorts in the US and around the world, and in service and religious organizations. As was the case with Charles Ponzi, what we know about the effects of what Madoff did is mostly about the substantial financial damage. We know a lot less about the victims, and the impact of their losses on their lives, and what they did after the Ponzi scheme was revealed.

In a program on PBS on Madoff after he was arrested, for example, virtually no attention is given to the victims beyond brief profiles of four individuals seemingly chosen because of what the media call compelling stories: the 
former mayor of Fort Lee, New Jersey, who lost \$5 million investing directly with Madoff and in one of his feeder funds; a law school dean, who suggested on his blog a government conspiracy in the matter; most ironically, a retired employee of Merrill Lynch, who, not surprisingly, was repeatedly interviewed by the press across the country; and a couple in their middle 70s, whose account of losing $85 \%$ of their life savings is overshadowed by their revealing that their ophthalmologist and his network of 33 family and friends had been "wiped out." It is from this last case that the seriousness of Madoff's crime might be most fully understood - instead of a comfortable retirement, the wealth of an entire family (grandparents, parents, and children) lost, and indigence. Indeed, it was found that the loss of intergenerational wealth was what most upset many of those Madoff victims who were part of this study.

The most obvious reason we know so little about whitecollar crime and its victims is that results seem less disturbing than those of violent crime - a corpse from a homicide, a mangled automobile after an intoxicated driver failed to heed a red light, a photograph of a terrified and bruised housewife beaten by a burglar or spouse. On the other hand, it is often difficult to put a face on the businesses, organizations, or the general public injured by the most common white-collar crimes - embezzlement, fraud, graft, illegal combinations in restraint of trade, misrepresentation in advertising, infringement of patents, adulteration of food and drugs, bribery. As has been repeatedly shown since the publication of Edwin Sutherland's exposition on white-collar crime in 1949, its consequences can be devastating.

Still, it is easily forgotten that after a white-collar crime is uncovered, when victims learn that they are in fact victims, the tale is far from over. There is still a great deal more to the story, well beyond assessing costs or losses. Of course, not all victims of white-collar crime attempt to redress their losses, but there are any number of ways to do so, perhaps the largest and most visible number resorting to the law. This paper focuses on a small number of the individuals who lost money in Madoff's Ponzi scheme and who became involved in the legal process.

I first describe who these individuals are and how their financial losses affected their lives. I then examine their efforts - in their own words - to make sure their victimhood is fully understood. For this, Madoff's sentencing trial is revisited as it not only provides more details about these victims, but also because the court is the public forum where those who violate the law often officially receive new and negative social identities, something that those whose savings Madoff had stolen hoped would be given to him.

The foundation of this study is an analysis of the universe of 167 written statements submitted to the court in
United States of America v. Bernard L. Madoff by his victims prior to his plea (29) and his sentencing (138). (Actually, more than these 167 victim impact statements were submitted to the court, but those too brief to provide more than a few pieces of useful information were put aside early in the study.) Of the total used, slightly over half are petitions to the judge requesting that Madoff not be shown leniency. Another 47 are from the "Ponzi Victims Coalition" - individuals primarily from Colorado - to the presiding judge, federal prosecutor, and the U.S. Senate Finance Committee, who, among other things, request assistance in obtaining restitution for monetary losses. An additional two dozen ask for the right to speak to the court and a handful offer suggestions about a variety of issues, for example, an appropriate plea or setting adequate bail.

Some submissions are co-authored, and some are written on behalf of a family member, in a number of instances those too old or despondent to write. Some individuals expressed themselves in half a page; others filled almost four single-spaced pages. The purpose of the impact statement, as specified by the courts, is that it "allows victims to personalize the crime and express the impact it has had on them and their families," which in this case the great majority of them do quite well. They allow those who see themselves harmed to express the extent they wish to see an offender punished. The victim impact statement can be more germane in a case like Madoff's, where an offender pleads guilty and avoids a trial, than when, with cross examination, the offense and the offender's responsibility are more completely examined, and, of course, when there are not multiple victims.

For our purposes, the victim impact statements permit us to more fully understand criminal activity by studying how those who see themselves as injured view the criminal, the crime, and their relationship to one or both, even if what they report might in fact be somewhat distorted. (In fact, we do not even know if all are truly victims; some surely could be exaggerating the extent of their victimization and losses.)

A 26 item coding schema was developed so that there would be uniformity in explicating the statement of each individual. There were many missing values; in fact, no submission provided information for all 26 items, and only a few came anywhere close to doing so.

The fact that these individuals publicly expressed their grievances, while the overwhelming majority of Madoff's victims did not avail themselves of this opportunity, makes it impossible to claim that these 167 individuals are representative of those cheated by this Ponzi scheme.

Of course, the overwhelming majority of financial risks in the Madoff Ponzi scheme were not to individuals or families, but to organizations, primarily financial ones. The leaders from a half dozen different countries were Banco 
Santander (a Spanish bank), exposed for $\$ 2.87$ billion; Bank Medici (an Austrian bank), exposed for \$2.1billion; Fortis (a Dutch bank), exposed for $\$ 1.35$ billion; HSBC (a British bank), exposed for $\$ 1$ billion; Union Bancaire Privée (a Swiss bank), exposed for $\$ 700$ million; Natixis SA (a French investment bank), exposed for \$554.4 M. This list reminds us that it would be an oversimplification to dismiss too quickly Madoff's victims as merely naïve investors whose greed blinded them to obvious folly.

\section{The Victims: A Profile and Analysis}

The majority of those who wrote and mentioned their age were 66 years of age or older. Many had recently left the work force or were at the point of retirement. All but one of them still working had put off retirement plans. Over a quarter said that their retirement plans had been completely ruined. Many of those most recently retired expressed regret about having done so and were pessimistic about the possibility of finding more than temporary, part time, or even low wage employment. They would be eager to take "demeaning" work if that was available. The circumstances of almost all had been significantly diminished. Not only had they been greatly harmed by their losses, but, in some cases, the harm extended all the way to quite elderly parents. In other cases, it extended to young grandchildren, and, in still other cases, across three generations. Almost $20 \%$ reported that their financial losses were multigenerational. The multi-generational economic ties of so many of these families appear to be slightly greater than what one would expect from what is written about the American nuclear family. That their investment losses were so harmful to their extended families was something those who wrote victim impact statements dwelled upon. The greatest concern was the reduced ability to assist their children financially. This was followed by the realization that they could not help pay for housing and medical expenses for aging parents or for their grandchildren's college education. A handful had disabled relatives whom they could no longer help support.

The largest number of individuals defrauded by Madoff resided in the northeast, and some who had lived there had retired to Florida and California in the last decade. Few could be described as wealthy. The overwhelming majority said that they were upper middle class (owners of medium sized businesses, physicians, attorneys), middle class (teachers, social workers, white collar civil servants), small business owners, or self described "ordinary Americans" or "typical Americans."

Although they seldom indicated the exact amount of their losses, about $10 \%$ did specify that it was a sum of over $\$ 1$ million. Close to one fifth who wrote about this matter in any detail indicated that "family money" or "family savings" were lost. What was lost, however, came primarily from their careers and savings, from what many described as "modest" or "frugal" lifestyles. As one victim put it, "as an entrepreneur, I worked hard and long hours for many years and never lived a lavish lifestyle. I understood the concept of "saving for a rainy day." ("Frugal" is mentioned in one-quarter of the letters, but not as often as "hardworking," found in half of the victim impact statements.)

In addition to losing retirement accounts, fully one quarter of these investors lost their homes. One third had lost their financial independence or financial security. The retirement of some was put in jeopardy, and about $10 \%$ reported they faced economic ruin, bankruptcy or destitution. A number of both men and women, married or single, even those well beyond retirement, indicated that they hoped to return to the labor force, although some expressed the belief that this possibility was small and unrealistic. Still, 15\% indicated that circumstances made them determined to return to work.

The well being of fully half had deteriorated in the few months after the full extent of Madoff's fraud was uncovered. Over $15 \%$ for whom information was available were burdened with new health problems believed to be precipitated by the stress of their situation. Over four times that number reported psychological harm - insomnia, periods of depression, anxiety, grief ("dissolving into tears"). The general health and family relationships of the others had become worse.

These individuals were clearly — before Madoff's Ponzi scheme was discovered - financially fully committed to him. Over four of five who mentioned it had had an account with Madoff for 10 years or more, one third for over 20 years. Of the 167,81 reported that they had given over all of their savings to Madoff and an additional 20\% reported that they had given over most of their savings to him. In fact, only four had invested as little as $50 \%$ of their nest egg with Madoff. The others had great trust in him, although the majority had never met him, and only four who had now acknowledged that they had found him charming or charismatic. (Two said that they had found him to be "very" charismatic and two said they found him to be "somewhat" charismatic. Another said that he seemed "genuine" and "kindly.")

In brief, these investors had exposed themselves to considerable financial risk over an extended period of time, and subsequent to their financial setback would have little opportunity for earning enough money to regain their financial security. Yet, they did not see themselves before or after they were fleeced — as having put themselves in a vulnerable position.

Now, the wrath of one quarter of those whose lives had been upended by Madoff had no limits. Over one third referred to him as a "thief," a "criminal," or a "disgrace." The language of nearly $20 \%$ was stronger, more vivid: 
"evil," "monster" (the most common epithet), "bastard," "devil," "psychopathic, lying egomaniac." He was compared to tyrants: "History shows us that there are monsters who think that they are above the law.... There are many examples: Adolph Hitler, Saddam Hussein, and Bernie Madoff." To them, Madoff had "committed a crime against humanity..., and he should be made to pay for his wicked deeds." (There are more examples in the Appendix.)

\section{Unrelenting Pressure}

For good reason, these victims of Madoff's Ponzi scheme are bitter and uncompromising. They all want their money back, although not all expect that in the end all will be returned. They surely want to see all of those who stole their money - their security - punished, and they have engaged themselves to see this happen. Not many of them use the language of justice. More use the language of vengeance. And even more speak of recompense.

There were other pressures. One of the 167 individuals who had written a victim impact statement was the coprincipal in a lawsuit against the trustee for the Securities Investor Protection Corporation (SIPC) claiming that he had treated her unfairly in adjudicating her claim. (Her attorney, who herself had invested with Madoff, had, in fact, written the court earlier with the demand that victims "must be given a seat at the table. To date, we have not been given that opportunity...in the bankruptcy proceedings...." She reminded the court that "people in their 90's are being put into nursing homes for the first time in their lives because their children can no longer afford to maintain them in private homes. People in their 70's and 80's, who retired with the assurance of a steady income from their Madoff accounts, are being forced to sell their houses in a depressed market in order to have money to buy food...." She asked that the government become more active in finding the stolen funds, and that the court "appoint a committee of investors [to help] assure restitution to Madoff's victims.")

At the center of the present lawsuit was a petition to replace the trustee after he had denied "prompt replacement of up to $\$ 500,000$ of ... securities as reflected on their November 30, 2008 statement received from Madoff' as "impracticable," since the statements reflected non-existent investments and were, of course, complete fabrications. In court the SIPC argued that "no one in their right mind" would use financial statements concocted by Madoff as a basis for calculating assets: "The last customer statement being a concoction of a fraudster is not something on which you can rely" in calculating net equity. The SIPC took the position that of the 15,870 claims that had been filed at that point only 2,336 were valid, as they were the only ones that had a net loss. The trustee's method for compensating investors was "cash in/cash out." In effect, with this decision, he had reduced the SIPC's liabilities from more than $\$ 7$ billion to approximately $\$ 1.2$ billion. (All of these numbers continuously change, and will for some time. At a later date, with more than 15,000 claims filed, the Madoff trustee Web site valued the total number of "allowed claims" at roughly $\$ 5.2$ billion.)

A bankruptcy judge, although sympathetic with the defrauded investors, concurred with the SIPC trustee, writing "the account statements are entirely fictitious, do not reflect actual securities position that could be liquidated, and therefore cannot be relied upon to determine net equity." He concluded that since securities were never "ordered, paid for, or acquired,...the only verifiable amounts that are manifest from the books and records are the cash deposits and withdrawals."

For her part, the attorney for the Madoff investors argued that the trustee's actions were "solely to enrich SIPC at the expense of SIPC's insureds." She expressed the seemingly overlarge concern that "aside from the devastation Picard [the trustee] has caused to thousands of customers, he has created a serious threat to the national economy because he is single-handedly destroying investor confidence in the capital markets." As she saw it, what he had done was not only unlawful, but a "violation of the public trust."

In the eyes of some of Madoff's investors, the effect of the SIPC's decision was to victimize them once again.

\section{Victims and Victimization}

It was an easy matter for those who suffered financial losses at the hands of Madoff to take on the role of victims, as that was the identity given them by the legal system, the media, and the public. Not surprisingly, all readily accepted this identity and adopted the appropriate vocabulary. That they suffered was proof to them of their victimization. Their victim impact statements were to convince others, as they had convinced themselves, they were merely innocent victims. They saw themselves as mostly "forgotten" victims, who had been "Madoffed." Surely - and not without good reason - they felt sorry for themselves. As they saw it, the fact that they lost money invested with Madoff automatically made them victims. Moreover, the less ambiguous the claim of having been victimized, the less of a need to consider one's responsibility for one's plight.

They were not the usual victims of contemporary America - of racism, sexism, capitalist exploitation, overbearing mothers, child neglect, a bipolar disorder, an inferior public education, or the tobacco companies - but victims of betrayal. Madoff did not fail them in that he tried 
to do the right thing but had not been successful. He had intentionally and cruelly wounded them: "We are not whining.... What happened to us was fraud and theft, not market loss." He betrayed the trust of individuals he knew and of individuals he had never met. He harmed those who planned to help others with their money. None considered themselves reckless or foolish, and certainly not greedy. They had trusted the professionals (their brokers and accountants) who, more than twice as often as had family and friends, recommended that they set up an investment account with Madoff.

The victim status is commonly a means of alleviating individual responsibility, and of reinforcing a sense of innocence. Most importantly here, being victims meant not having to take moral or legal responsibility for the decision to invest a significant percentage of one's savings, retirement account, or family trust fund with Madoff. They considered themselves blameless. Only two of those writing victim impact statements acknowledged any responsibility for financial losses. Only one individual wondered whether his outcome would not have been so disastrous if he had diversified his portfolio. Moreover, the simple fact of being victims also distanced them from Madoff's actions.

More than just a handful of the writers of the victim impact statements go further than simply explaining that what happened to them was unfair, grossly unfair. They seem unaware that the world is far from perfect, indifferent, and sometimes hazardous. They insist that in this instance it be made perfect. They not only want the government to punish Madoff, they want it to erase the damages caused by him. Their entitlement, earned from a life of "hard work," sacrifice, and frugality, demands it.

Like many who see themselves as victims, they believed that they were deserving of total justice, and a number were convinced that this could only be achieved by litigation.

\section{The Sentencing Trial}

A criminal prosecution is a process not only to punish criminal activity, but also to publicly discredit a criminal. A criminal prosecution has all of the qualities of a degradation ceremony wherein an individual is stigmatized before the entire community, sort of like a graduation ceremony in reverse: the person on trial becomes part of a ritual to be publicly labeled in a negative rather than positive way. As Garfinkel put it, "structurally, a degradation ceremony bears close resemblance to ceremonies of investiture and elevation." Degradation ceremonies, Garfinkel adds, can be found in all societies, except those that are completely demoralized. In thinking about degradation ceremonies in Western societies, what immediately comes to mind are the Holy Inquisition, the witchcraft prosecutions in Renais- sance Europe, the Stalinist purge (the "Great Terror") in the Soviet Union between 1936 and 1938, and the Salem Witchcraft episode.

In contemporary society, the task of carrying out a degradation ceremony is typically, although not exclusively, given to the courts and its officers. Criminal trials, like all degradation ceremonies, provide a formal stage on which communities confront individuals accused of having violated the law, and through a ritualized process decide innocence or guilt. If individuals are judged to be guilty, they are given a new identity, which the community deems will prevent further criminal activity.

The degradation ceremony is a useful conceptual framework to help illuminate Madoff's sentencing hearing.

It was not necessary to browbeat or physically coerce Madoff. He readily admitted his guilt to eleven felonies securities fraud, investment adviser fraud, mail fraud, wire fraud, international money laundering to promote fraud in the sale of securities, international money laundering to conceal the proceeds of fraud in the sale of securities, money laundering, making false statements, perjury, making a false filing with the Securities and Exchange Commission, and theft from an employee benefit plan. As odd as it may seem to many, it has been suggested, in fact, that he exaggerated the amount of his swindle in the hope of enhancing his reputation, much like an accused witch in 1692 claiming supernatural, demonic powers.

Nonetheless, in spite of the fact that Madoff surely faced a long prison term, many victims expressed the desire to become part of the sentencing hearing. The judge permitted nine of those who wrote impact statements to speak in open court before Madoff was sentenced. Participation by the victims in Madoff's criminal prosecution, the purpose of which was to formally change his identity, made it the quintessential degradation ceremony. One essential element was Madoff, who was admittedly blameworthy. The other essential element was the nine witnesses who unmercifully denounced him. To have maximum effect, denouncers in a degradation ceremony must show, among other things, that the perpetrator greatly harmed the community, and that they speak in the name of the ultimate values of the community. Witnesses must also distance themselves from the deviant act. In what they wrote to the judge and what they said, Madoff's victims seemed effective in discrediting him. They wanted him labeled in a negative way, stigmatized, and fully punished, regardless of what he or his attorneys had to say to mitigate his behavior.

\section{The Ritual}

As it is widely understood, a criminal prosecution is a process not only to punish criminal activity, but also to discredit a 
criminal publicly. But before the ritual moves into its final phase, the accused and convicted are given an opportunity to justify their actions, to explain, to defend themselves.

In a three-page written appeal for leniency, Madoff's attorney, after acknowledging the severity of Madoff's crime, using argumentum ad misericordium, a technique in the quiver of all defense lawyers, immediately portrayed Madoff as a victim, a victim of shocking "death threats and anti-Semitic e-mail." He went on to contend that the victim statements might be discounted as they suggested "a desire for a type of mob vengeance that, if countenanced...would negate and render meaningless the role of the court." The key element of the appeal was to remind the judge twice that Madoff "turned himself in," "accepted full responsibility," "expressed regret and remorse," and had shown "his desire to cooperate in asset recovery."

Speaking in the courtroom the following week, the defense attorney showed considerably more sympathy toward those duped by Madoff: "There is no way that we cannot be insensitive [sic] to the victims' suffering." $\mathrm{He}$ characterized their situation as a "tragedy," but dismissed their contention that Madoff deserved an extended prison sentence as simply seeking "an eye for an eye." He assured all that "we have worked...diligently...trying to recover assets...[to the point that even left] his wife impoverished." To pursue "vengeance and revenge" with an extended sentence is "bordering on the absurd."

For his part, Madoff began by admitting the obvious, namely, that over the years he had done "a great deal of harm," although, he was quick to add, it was "not... intended." The motif of his three-paragraph statement was to acknowledge that he regretted "the pain and suffering that I have created," "the pain and suffering I have caused," and "the pain and suffering I caused [my victims]." $\mathrm{He}$ repeats the word "mistake" a number of times — "terrible mistake," "trading mistake," "tragic mistake." He theatrically concluded: "I apologize to my victims. I will turn to face you. I am sorry. I know that doesn't help you."

No members of Madoff's immediate family were in the courtroom in his support, although after he was sentenced, his wife followed with an equally brief statement about how she not only felt misunderstood, but also "betrayed" and "devastated," and how she "aches" when she hears about the harm her husband caused. She, too, apparently saw herself as a victim.

What was said by Madoff or in his defense could only briefly forestall the public degradation that was to become as much a part of the court proceedings as was the doling out of the prison sentence - 150 years, three times as long as the federal probation office suggested and 10 times as long as his team of attorneys had requested after their analysis of the average length of sentencing for other severe acts of financial fraud.
The government attorneys took the first step in Madoff's degradation. In their sentencing memorandum, they characterized his crimes as being "of extraordinary dimensions," spoke of him as being "engaged in wholesale fraud for more than a generation" ["at least as early as the 1980s"]: "his business was a fraud; his fraud affected thousands of investors...; and he repeatedly lied under oath and filed false documents to conceal his fraud." Everything about him was a deception. The government attorneys also reminded the court that "Madoff chose instead to abandon honest work to pursue riches and influence through crime, and he used the proceeds of those crimes to enjoy a lavish lifestyle that included well-appointed homes in Montauk, New York, Palm Beach, Florida, Cap d'Antibes, France, and on Park Avenue in Manhattan" - places most others only read about or briefly visit as tourists. The attorney who spoke for the government added to these denunciations, using such terms as "stole ruthlessly and without remorse," "destroyed," "calculated, well orchestrated, long-term fraud," "lies...nothing but lies," "economic ruin," to describe Madoff and his behavior.

\section{Lending a Hand: The Victims Speak}

The first of the nine permitted by the judge to speak, portrayed himself "as a victim of an indescribably heinous crime," as having his "entire life savings drop right out from under [his] nose." "How can we pay our bills?" he asked. He added that, "we worked honestly and we worked so hard.... We did nothing wrong." Now, he and his wife had lost "the security of our savings," and "we are left with no permanent house." For shelter, they had become housesitters for extended periods of time. His pension "is all we have," but, he emphasized, his wife would lose those benefits [both income and health insurance] if he died. He pointed to the added burden of health problems: an over $50 \%$ hearing loss on his part and that his wife's foot had been run over by a van. And there was more involved than material things: "The most devastating to us is we lost our freedom. We lost the ability to share our life every day as we explore the country every day. We lost the time to hold hands as we walked."

The second denouncer, "a 61-year-old widow...now working full time" at "three jobs at the same time" also "lost all of my life's hard-earned savings:" "I must work full time in order to eat." She described being forced to sell "a lot of my possessions," including the home "I had owned for 25 years," and her automobile. She was concerned that she would become a burden when she became "sick and old." She had already accepted gifts of money to pay for heat, electricity, gasoline, and food. She described the devastating emotional toll and her deteriorating health due 
to Madoff's theft: "I could not eat or sleep. I was very agitated and hyperactive....I suffered rapid weight loss, rapid heart rate, sweating, insomnia, and sometimes spells." She refused to believe that Madoff was being truthful about feeling guilt and shame. She doubted that Madoff had acted alone, as he contended, and thought that he had been helped by many others, starting with the federal government: "There are many levels of government complicity in this crime. The Securities and Exchange Commission [SEC], by its total incompetence and criminal negligence, has allowed a psychopath to steal...."

The third denouncer characterized Madoff's actions as treachery. He too had lost his "entire life savings." $\mathrm{He}$ described how he and his wife had "worked hard, long and hard" all of their lives, but he too was now "forced to work three jobs." Madoff's premeditated and calculated crime had robbed him of his retirement, and even an opportunity to visit his 1-year-old grandson. As he saw it, Madoff was "a common thief," an "evil lowlife," who had shown no remorse, and who should be given "the maximum sentence at a maximum prison," as "his was a violent crime without the use of a tangible weapon." Indeed, he was adamant that Madoff not be shown any leniency: "It is impossible to compare his crime to any past criminal act." He concluded with personal and theatrical themes, first quoting his own wife before fully condemning Madoff: 'I cry every day when I see the pain and despair in my husband's eyes. I cry for the life we once had before that monster took it away.' Finally, "you have a marriage made in hell, and that is where you, Mr. Madoff, are going to return. May God spare you no mercy."

The fourth denouncer also stressed that her family was not wealthy, simply ordinary, middle class Americans: "we were never rich people. We have worked [as a glazier and physical therapist] all of our adult lives.... We have both diligently saved our hard-earned money." She too "lost our entire life savings ... [to be used for college tuition] and a secure retirement." My mother "may not have enough money to maintain her home and living expenses." Moreover, she added, "the turmoil caused by our financial devastation has caused us serious physical and emotional problems for which we need medical treatment." She concluded by suggesting that Madoff be sent to a maximum security prison.

In a brief statement, the fifth denouncer describes how she lost her mother, her inheritance, and her own savings in a short period of time. She saw what Madoff had done as "despicable": "He destroyed my life, and I have no other assets.... For the first time in my life I am very, very frightened of my future."

The sixth denouncer told how he lost his inheritance, his retirement accounts, and his children's trust fund; a total of $\$ 5$ million. As he saw it, Madoff, "the most despised person to be in America today," was not "genuinely remorseful," so that "when [Madoff] leaves this earth virtually unmourned," he expressed the wish that "Satan grow a fourth mouth" where Madoff will "spend the rest of eternity [with Judas, Brutus, and Cassius]."

Madoff's company had also taken the seventh denouncer's "life savings": "I was wiped out." Some of the money Madoff stole from him had been set aside for his twin brother, who was mentally disabled. As he put it, "my family wants to remember that in addition to stealing from retirees, veterans, widows, Bernard Madoff stole from the disabled." He concluded that because Madoff "killed dreams..., [I hope] that his jail cell becomes his coffin."

The eighth denouncer began by making the claim that Madoff "had stolen everything I had," and she was enraged: "his words and deeds beat me to near senselessness. He discarded me like road kill." She was left destitute: "At the end of the month I sometimes scavenge in dumpsters. I cannot afford new eyeglasses....Sometimes my heart beats erratically for lack of medication when I cannot pay for it.... My laundry is done by hand in the kitchen sink...I have collected empty cans and dragged them to redemption centers." And she anticipated that her situation would get worse, as in "only a matter of time, I will be unable to support my beloved sister." She was confronting a man whom she saw as truly evil so that he would "acknowledge the murderous effects of your life's work....Forgiveness for now, it will have to come from someone other than me."

In a lengthy denunciation, the final speaker began by describing herself and all of her extended family, who lost "everything," as "ordinary working people, worker bees." Just the previous week she and her husband had been forced to sell their home. Four years earlier they had refinanced it, and had invested the excess cash with Madoff. Deeply angry and depressed and what she described as autophobic, she could not eat. Six times in her testimony she referred to Madoff as a "beast," and three times as a "monster." As a consequence, the community should "keep him in a cage behind bars."

In addition to what was said in the courtroom, viewers could not ignore the grief and the tears. There were loud voices. Many were particularly struck by a witness who used a walker. The degradation ritual seems to have been cathartic for more of Madoff's victims than those who publicly condemned him. Scheff has observed that in modern society "ritual increases distance from distress," that it has the potential "of meeting individual and collective needs simultaneously, allowing individuals to discharge accumulated distress and creating social solidarity in the process." Almost all of those in attendance and almost all of the press accounts describing the courtroom after the victims spoke indicate that this is precisely what occurred. 
As in all such degradation ceremonies, the final denunciation belonged to the judge. He began by describing Madoff's fraud as "staggering" and "unprecedented." He condemned what Madoff did as "extraordinarily evil... [that has taken] a staggering human toll." He also noted that no family, friends, or associates had submitted letters to the court attesting to Madoff's character or the good deeds he had done. The nine victims who spoke to the court seem to have made an impression on the judge, and, perhaps, led to his decision: "As the victims' letter and e-mails demonstrate, as the statements today demonstrate, investors made important life decisions based on these fictitious account statements - when to retire, how to care for elderly parents, whether to buy a car or sell a house, how to save for their children's college tuition."

I was particularly struck by one story that I read in the letters. A man invested his family's life savings with Mr. Madoff. Tragically, he died of a heart attack just 2 weeks later. The widow eventually went to see Mr. Madoff. He put his arm around her, as she describes it, and in a kindly manner told her not to worry, the money is safe with me. And not only did the widow leave the money with him, she eventually deposited more funds with him, her $401(\mathrm{k})$, her pension funds. Now, all the money is gone. She will have to sell her home, and she will not be able to keep her promise to help her granddaughter pay for college.

While his clients' lives were being upended, the judge noted, Madoff was using the funds from his firm for "the purchase of a Manhattan apartment for a relative, the acquisition of two yachts, and the acquisition of four country club memberships at a cost of $\$ 950,000$.”

As in all degradation ceremonies, the primary actors spoke as the conscience of the community. They reminded their listeners that not only they, but the entire community had been gravely injured. But for them, the injury was also a personal betrayal, and their outrage seemed to know no bounds. All but one or perhaps two distanced themselves from Madoff; no one shared his responsibility or blame. They had not made imprudent investment decisions. They had not lost their money; it was stolen from them. The denouncers repeatedly took pains to portray themselves as typical community members.

Madoff was clearly a despised man, an outcast of society. No financial advisor in history had behaved so egregiously. It is hardly surprising that there were so many allusions to his dying. Although their financial losses totaled only an infinitesimal amount of Madoff's huge theft, what these victims said, and had written, underscored how much pain he had caused so many individuals. Their testimony, by putting a human face on what might otherwise have been considered an outsized, but not extraordinary white-collar crime, left Madoff, convicted by both the court and by public opinion, close to universally detested. White-collar crime in which billions of dollars are slowly or suddenly lost, often by financial institutions or governments, is not that unusual, and barely catches the public's attention. The actions by his victims pretty much assured that unlike, for example, Michael Milken today simply described as a financier and philanthropist, that Madoff's stain would be permanent.

For the community, the ceremony was clearly successful. Madoff was a convicted felon, with a new identity of federal prisoner no. 61727-054, facing 150 years in the penitentiary. He was transported to U.S. Penitentiary Atlanta, the prison that had housed Charles Ponzi a hundred years earlier. Two weeks later, Madoff was transferred to the Federal Correctional Institution in Butner, North Carolina, with an initial possible early release date on November 14, 2139.

Even with the matter of Madoff's freedom completely settled, there was no pause in the efforts of his victims to recover their lost money and to continue to vindicate themselves. Often framing their efforts as the pursuit of justice, they frequently turned to the courts.

\section{The Assault on Government}

To help insure that they could not be blamed for their financial losses, the accounts Madoff's investors provided of their financial distress shifted attention to the federal government as often as to financial institutions. Over two thirds of those who submitted victim impact statements concluded that they had been left not only feeling vulnerable, but disillusioned. Most had lost faith in humanity, in general, and in the future. Those who were more specific often stated, again not surprisingly, that their faith in the financial system was greatly diminished. Actually, however, a larger number blamed the federal government for leaving them financially vulnerable.

As they saw it, they were victims not only of Madoff, but also of the federal government. It was as if by projecting guilt on the government, they could fully wash away even a hint of responsibility on their part. They clearly wanted to avoid any blame. If not only Madoff, but the government, were fully guilty, then by investing in Madoff they could not have been making a mistake. The more parties there were to blame, the more they could deny responsibility. They could not have acted carelessly.

Some questioned the competence of government regulators; a few wondered if government officials were simply dishonest.

They were, first of all, critical of the government for allowing Madoff to steal from them. In general, they were a 
great deal less passionate in their vilification of the government than in their vilification of Madoff. But they were clearly angry. They were angry that government officials had permitted Madoff to operate for so many years, but also for seemingly doing so little to make them financially whole. They most often blamed the SEC and the SIPC and their officials (some mentioned by name), and much less often the judicial system for granting Madoff bail and the prosecutor for not working on their behalf to keep Madoff behind bars, to find his co-conspirators, and to force his family to return more of the stolen money. For the most part, their anger at the government was not hysterical, merely undisguised and relentless. Of the total, $25 \%$ blamed the government for contributing to their initial financial troubles before Madoff confessed; a higher number believed that the government's actions and inactions were responsible for their continued financial woes. There was a clear attempt to put the government on trial.

Since the elements of white-collar crime were first outlined by Sutherland, criminologists have contended its genesis is in differential association. As Sutherland put it: "The hypothesis of differential association is that criminal behavior is learned in association with those who define such behavior favorably and in isolation from those who define it unfavorably, and that a person in an appropriate situation engages in such behavior if, and only if, the weight of the favorable definitions exceeds the weight of the unfavorable definitions." In short, this suggests that it is unlikely Madoff operated in a vacuum, alone or nearly alone. However, neither being social theorists nor looking beyond their own plight, only a small minority of the victims suggested that the federal government actively pursue Madoff's collaborators, although surely some mocked his wife, brother, sons, and team of expensive attorneys. If the blame was to be shared, they believed that government officials were more appropriate targets of their wrath than the investment community surrounding Madoff. There was nothing wrong with Wall Street, merely "bad apples" and incompetent officialdom, who were duped, dishonest, or half asleep.

\section{Summary of the Victims' Perspective}

Although not strictly part of court proceedings, testimony by one of the167 individuals who had written a victim impact statement to a panel of the House Financial Services Committee holding hearings on "Assessing the Madoff Ponzi Scheme and the Need for Regulatory Reform" provides considerably more information than he provided in his initial letter, and also encapsulates so many of these findings that it can serve as a near perfect summary of the perspective of the victims, and of what was found in the foregoing analysis.

Witness: "I held an IRA retirement account with Mr. Madoff's firm for approximately 21 years. I am 76 years old, and until my retirement I worked in a textile trade buying and selling fabrics for use in women's apparel. My wife, Ruth, and I have been married for 52 years. For the past 16 years we lived quietly in the Taconic Mountain region of New York State....

"In the blink of an eye, savings that I struggled my entire life to earn have vanished.

"Like many of Mr. Madoff's victims, we are hardly super-rich. I was born and raised in the Flatbush section of Brooklyn, in a one-bedroom apartment with my parents and sisters. I worked my way through New York University with two jobs to pay tuition. After school I spent 2 years in the army, including 16 months in Korea....

"Throughout that time [the 1970s and 1980s] I always remained very conservative with my money, investing it prudently and keeping a good deal of it in money market funds. By the late 1980s, I managed to accumulate approximately $\$ 1.8$ million in my IRA. My accountant took note of the slow returns from the money market fund, and recommended me to Madoff Securities. He told me that Madoff generally achieved 8 to $12 \%$ return per year, and he employed a conservative proprietary hedging strategy that moderated market risks.

"In the late 1980s, I transferred \$1 million from my IRA to Madoff. I received account statements every month showing gains of 8 to $12 \%$ annually....

"In the mid-1990s, I moved the rest of my IRA savings to Mr. Madoff., approximately another \$1and-a- half million. Since retiring in 2001 at the age of 69, we have used our savings at Madoff to pay our mortgage, taxes, and general living expense. By November 2008, our Madoff account had reached approximately $\$ 4.2$ million in stated value....

"I have been forced to cash in my life insurance policy to pay my mortgage. We are forced to sell our home, and with the real estate market the way it is, we probably will not find a buyer and be forced into foreclosure....

"I sit before you a broken man. Throughout my life I always believed the American system of capitalism was the best regulator in the world.... But the Madoff 
scandal and the SEC's inability to detect it, despite repeated written and other warnings, have taught me this is not the case.

"I believe my government has failed us, and we have suffered tragically as a result. As with many other Madoff investors, the past several weeks have been a difficult waiting period for my family and me....

"Our current reality has nothing to do with profligate spending or undue market risk. We conducted our affairs in good faith, and believed that the SEC would never allow this sort of scheme to be conducted."...

Rep. Kanjorski: "And then the question of due diligence - where does it really lie? Does it lie with the investor or does it lie with someone else?" ...

"I'm absolutely shocked in terms of an experienced businessman, successful, hesitant, when you took some of your money from your IRA and gave it to Mr. Madoff Investments...."

"What was the compelling reason? Was it the advice of your accountants that made you select the Madoff outfit, or did you actually check them out in some way? How did you get to them, I'm curious?"

Witness: "It was advice of my accountant."...

Rep. Kanjorski: "Is there any relationship — was he a finder, your accountant, for Mr. Madoff?"

Witness: "No."..

Witness: "I think that he invested money with Mr. Madoff also."...

Witness: "I was prepared for risk. I wasn't prepared for fraud."

Rep. Kanjorski: "Well, isn't fraud a potential risk factor that ought to be considered?"

Witness: "To my mind, no, because the securities industry is regulated by the Securities and Exchange Commission to prevent that kind of thing - in my mind."...

Witness: "But this was a fraud."...

Rep. Kanjorski: "Well, couldn't you have insured against dealing with fraudulent people?" ...

Witness: "I don't have anything like that, but I always thought that SIPC would do that."...

Rep. Capito: "Did you actually interact personally with Mr. Madoff at all during any of these transactions?"

Witness: "Never met him."
Rep. Capito: "Never met him."

Witness: "No."...

Rep. Ackerman: "How much do you have left in cash value in your life insurance?"

Witness: "None. I took it all out."

Rep. Ackerman: "You took it all out for what purpose?"

Witness: "To pay my mortgage, to pay my living expenses [food].”...

Rep. Ackerman: "What month are you paid up to on your mortgage?"

Witness: "My mortgage is paid through January."...

Rep. Ackerman: "Can you pay it next month? Can you pay it the following month? Can you pay it for the next 3 months?"

Witness: "I think that I can pay my mortgage for the next 2 months, February and March.”...

Witness: "Well my daughter in California has told me that she would put my wife and myself up in her house."

Rep. Ackerman: "How does that make you feel?"

Witness: "Well, at this stage of my life, the thought of living in my children's home is - not humiliating but it's very sad, it's terrible. It's terrible."...

Rep. Ackerman: “And I appreciate your wife's willingness although she could not be strong enough to be with us today...."

Witness: "My wife is going through emotional problems because of this."...

Witness: "I'd just like to say one thing. I never thought a fraud in this. It was an investment that looked perfectly fine, I was getting a return. But somewhere inside of me was the thought that this was a regulated industry, and the government was behind the regulation. And it wasn't, it wasn't. The red flags, the warnings, the letters were just pushed aside. So the end result was people like me are suffering because of that."...

Witness: "I say - I'll say exactly what I said before. I invested my money. The market goes up and the market goes down. I understand that. But I also invested my money knowing somehow that the government - the SEC — whatever laws were involved were protecting me from fraud. Not from market volatility — market volatility is my own 
problem. Fraud on the scale that it was perpetrated I think the government has some complicity. There were warning signs. There were letters. There were audits that weren't made. There was an accountant that didn't fit into the picture. There were so many things that happened and nobody did a thing about it. So we were all victims."

Clearly, there is no better way than reading this witness's words to understand the world of Madoff's victims. It is important to note that as this victim's testimony continued, he expressed an ever greater conviction that the government was responsible - that it was "complicit" - for his losses. He was treated at all times with courtesy and respect by the members of congress, and often praised for his willingness to give testimony, although as the entire transcript makes clear, not all were as willing to fault the government for his misfortune.

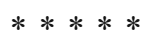

It will be recalled that in her opposition to the SIPC decision not to reimburse Madoff's investors to the extent that they believed fair, the victim/attorney concluded that this would ultimately harm the confidence of all investors. Her assertion might seem an exaggeration, or might be dismissed as simply a debating point. However, she is not the first to make such an argument. In fact, she was simply restating an idea that has been long understood and embraced, and which is sociologically self evident, namely that fraud and betrayal greatly undermine social life.

Of the various sins delimited by Dante in the Divine Comedy (lust, gluttony, avarice, prodigality, wrath, sullenness, heresy, violence, fraud, and betrayal), fraud and betrayal are deemed the most serious. Lust, which we take most seriously, Dante thought most trivial, those guilty of it condemned to just beyond the first circle of Hell. Fraud and betrayal, which we often take lightly, Dante believed most serious. For Dante the most wicked, those guilty of fraud or of betrayal are condemned nearest the center of Hell. To lie, to be dishonest, is to break one's faith with others. Dante understood that the bond of faith was at the foundation of social relationships, the building blocks of social life, not only economic life. As a result of fraud and of betrayal, society would quickly descend into chaos.

Undoubtedly, Madoff's fraud will continue to have negative social repercussions for years to come. The hurt will be felt by others beyond those who suffered monetary losses. As the victim/attorney saw it, not only what Madoff did, but the intransigence of the SIPC trustee "has created a serious threat to the national economy because he is single-handedly destroying investor confidence in the capital markets." To the degree that she is correct in faulting the response of the government as being inadequate, what Madoff did might, indeed, go well beyond simply the economic and psychological harm that have been detailed here.

However, although economic fraud may transcend the economic world, it might not be the case that undoing economic fraud, by whatever means, will have the slightest effect on the far reaching damages it has caused.

\section{Appendix}

Excerpts from Victim Impact Statements in Madoff Case

To present a fuller picture of these individuals and the statements' contents and tone, this Appendix consists of excerpts from eleven statements, five are written by those whose last names begin with $\mathrm{B}$ and six are written by those whose last names begin with $\mathrm{F}$ :

RB. "We have a 16-year-old daughter. We took her to New York [from California] three years ago to meet Bernie Madoff. He had the gall to shake her hand as we thanked him for taking such good care of our money - her college money - and all of our extended family's money. He robbed us not only of our money, but of our faith in humanity, and in the systems in place that were supposed to protect us."

KB. "My father and I had our life savings invested with him.... We now have nothing. [We are] only living off social security. I told my father (89) he could not die because I didn't have enough to bury him."

BB. "My husband and I had an account for over 30 years with Madoff.... As seniors now, we saved almost \$1 million to find on Dec. 11, 2008 that it was all gone!!!... My 89-year-old mom and 90-year-old stepdad, also had an account with Madoff and lost their life savings of around $\$ 300,00[0]$. They are practically destitute, and ill, I cannot help them.... PLEASE SEND THIS PERSON TO JAIL FOR LIFE!! AND MAKE SURE HE NEVER SEES THE OUTSIDE OF PRISON AND IS NEVER FREE AGAIN!!!"

PB. "My family (which includes my mother, brother and me) has lost our life savings with Mr. Madoff. I was widowed at the age of 39 and left to raise two children. I took my husband's life insurance money and invested with Madoff Investment Securities.... I am 61 years old and not yet collecting Social Security so I am presently trying to find employment. The company I previously worked for closed and moved out of town.... I have had to move my mother in with 
me as she has lost all her money with Mr. Madoff, too. I have had to pay for home renovations to accommodate her needs and am trying to make ends meet.... We have never lived beyond our means and had hoped that we were secure with our investments."

EB-S. "For 30 years, I worked as a forester for the City of Boulder's Park and Recreation Department. I retired a year ago thinking that I had a nice nest egg to live off of.... We lived under our means for many years saving money...for our daughter's college education.... Ironically, now I find that I don't have any money to send my daughter to college.... Like many, our savings have been completely wiped out. Now middle-aged, we have to start over and try to rebuild.... We will eventually have to sell our home while having to help support both our parents since they also had money in what was once known as a safe and well managed investment firm. I can't tell you how scattered [sic] we feel-it goes beyond financially. It reaches to the core and affects your general faith in humanity, our government and basic trust in our financial system."

SF. "I am e-mailing you how we lost $80 \%$ of our savings with Madoff. I have always been, professionally, a Special Education Teacher.... My wife is retired with a back disability; we have a 13- and 16-year-old in public school. We had only $\$ 330,000$ on our last statement. We have not used the income from this, but this year my mom, 97 years old, ran out of money and it costs us $\$ 3,000$ a month for her and we are using up our equity line each month. We have a lot of health bills for my wife and mother... I am now retired but continuing to work part time to keep some extra [money] coming in...."

NF. "I am completely wiped out; a client for 12 years [we] gave him all of our savings and sale of our home, business and all other savings. Why not - he had an impeccable reputation, backed by the SIPC, none of the HEDGE funds could offer that, even though they were paying $17 \& 19 \%$ returns and Madoff only $8-9 \%$, he was safe. We are in our 70 s, cannot get employment, have no idea how we are going to live in our home and exist. I do not know how I am going to live after living off my investment. Mr. Madoff should not have that problem; he should know where he is going to live for the rest of his life."
LF. "I am an 80 year old man in poor health whose remaining years have been totally devastated by Bernard Madoff. My wife and I have left every dollar of our life savings in Madoff's fraud scheme with no hope of recovery. We have had to sell every asset that we own in order to survive and we don't know how long these proceeds will last. I cannot begin to describe to you the toll that Madoff's actions have taken on us financially, physically, and emotionally.... Mr. Madoff is a ruthless and unscrupulous man with no conscience or remorse.... We will spend the rest of our lives in financial ruin and emotional and physical devastation."

AF. "I am 86, a widow, and a victim of Madoff. My husband was a school teacher and I worked as a school secretary.... We put all of our hard earned savings and IRAs into Madoff. What do I do now? I have been wiped out - I cannot get a job - who would hire me now?"

AF. "My father was a gastroenterologist in Huntington, Long Island. As an example of the kind of business he ran, when his patients could not pay him, he accepted payment in kind. I remember him bringing home a bag of potatoes once.... Both of our parents suffer various medical ailments. On top of that, Dad suffers dementia.... Our mom has dementia now as well, to a lesser degree.... Our parents wanted to help their grandchildren, too. One of their grandchildren has juvenile diabetes, one [has] schizophrenia, [and] one plans to go to law school.... Our parents didn't, and don't, deserve to lose everything.... Bernard Madoff's utter abrogation of that trust was not only heartless and cruel, but chillingly systematic. Madoff lied to, and thus stole from, my parents ON A WEEKLY BASIS, with every weekly packet of confirmation slips that he sent out.... And, because they invested with him approximately two decades ago, that means that Bernard Madoff lied to them, and stole from them, 1,000 and 40 separate times."

Lionel S. Lewis (A.B., Washington University; M.A., Cornell University; Ph.D., Yale University) is professor emeritus of sociology, SUNY/Buffalo. $\mathrm{He}$ is the author of 5 books and the author or co-author of 130 research articles, essays, and reviews, a number published in SOCIETY. This article is the first in a planned series on the Madoff Ponzi scheme. 